ISSN 2078-6441. Вісник Львівського університету. Серія географічна. 2013. Випуск 41. С. 3-11. Visnyk of the Lviv University. Series Geography. 2013. Issue 41. P. 3-11.

626.87:631.62 (477.8)

\author{
т лія єлов 1 \\ рик рп тський н ціон льний університет імені силя теф ник, \\ вул. евченк, 57, 76018, м. в но- рнківськ, кр їн, \\ e-mail:inst@pu.if.ua
}

ро н лізов но суч сну структуру осушув них земель грол ндш фтів ередк рп ття в розрізі дміністр тивних обл стей. х р ктеризов но н йбільші осушув льні системи регіону, н ведено кількісні пок зники земель 3 іхнім типом осушення. осліджено розподіл осушув них земель у меж х меліор тивних систем т под но їхню еколого-меліор тивну оцінку. ведено прикл ди високоефективного використ ння осушув них земель. исвітлено нег тивні екологічні процеси, що розвив ються н меліоров них землях регіону.

лючові слов : грол ндш фт, осушув ні землі, осушув льні системи, меліор ція, ередк рп ття.

природно-клім тичними особливостями ередк рп тський регіон н лежить до зони н длишкового зволоження (коефіцієнт зволоженості - 1,1-1,2) [10]. ільше половини річної суми оп дів вип д є в теплу пору року, що в поєдн нні з густою гідрогр фічною мережею сприяло формув нню тут з болочених і перезволожених земель. собливості рельєфу, різном нітність м теринських порід т різн глибин з ляг ння грунтових вод зумовили зн чну строк тість грунтового покриву досліджув ного регіону, для підвищення родючості якого у 60-80-х рок х ст. проведено широком сшт бні меліор тивні роботи. роте, як свідчить оцінк ст ну осушув них земель н території ередк рп ття, меліор тивні з ходи не з вжди й не всюди створюв ли сприятливі умови для розвитку і росту сільськогоспод рських культур. сновною метою цих з ходів було: “... зниження рівнів грунтових вод і грунтових верховодок до розр хункових норм осушення, прискорення відведення н длишкових гр віт ційних т поверхневих вод з орного горизонту грунтів” [10, с. 72]. рив ле осушення т нер ціон льне використ ння меліоров них земель призвело до докорінних змін у структурі грол ндш фтів. собливо це позн чилося н його мобільних компонент х - рослинності й грунт х $[7,8]$. ст нніми рок ми зн чно зменшил сь продуктивність осушув них земель, що прямо вплив $є$ н зниження продуктивності с мого грол ндш фту. ому досить кту льною є проблем розробки теоретичних основ створення високопродуктивних стійких грол ндш фтів т $\mathrm{p}$ ціон льного використ ння осушув них земель 3 ур хув нням перспектив розвитку землеробств і меліор ції.

ш мет - дослідження суч сного ст ну функціонув ння осушув них земель т їхній розподіл в грол ндш фт $\mathrm{x}$ ередк рп ття т в меж х меліор тивних систем регіону.

1 уковий керівник: лійник силь теп нович - доктор сільськогоспод рських н ук, професор к федри геогр фії і природозн вств рик рп тського н ціон льного університету імені силя теф ник, м. в но- р нківськ.

(С) єлов ., 2013 
ля з'ясув ння цього пит ння в умов х ередк рп ття про н лізов но ст тистичні д ні упр влінь ержкомзему у ьвівській, в но- $\mathrm{p}$ нківській т ернівецькій обл стях про н явність осушених земель, їхній розподіл з вл сник ми т угіддями. крім того, використ но річні звіти обл сних виробничих упр влінь водного господ рств т меліор ції щодо функціонув ння меліор тивних систем. ежі ередк рп ття визн чені 3 публік цією [6]. егіон охоплює повністю шість дміністр тивних р йонів і ч стково 19, що розміщені у відповідних обл стях. сі розр хунки проводили в розрізі територій сільських р д ст ном н 01.01.2012 p.

цінку ст ну осушув них земель т їхній вплив н продуктивність грол ндш фту неоднор зово досліджув ли з різними методик ми геогр фи, грунтозн вці т екологи. окрем, численні дослідження щодо зниження родючості т дегр д ції грунтів під впливом меліор тивних робіт висвітлені в публік ціях . олощук , . епут т, . кимів, . змір т ін. [5, 7, 8]. уч сний ст н функціонув ння осушених земель ередк рп ття дет льно сх р ктеризов но в пр цях . рбівської, . ількевич ,

ельник [5, 9]. ит нням дослідження і поліпшення ст ну осушув льних систем 3 йм лися . ерещенко, . ельник т ін. [11]. цінк громеліор тивного ст ну земель окремих регіонів н веден в пр цях . озловського, . ожегової, . люк, щик $[1,3,4,10]$.

ередк рп ття - один із сільськогоспод рських регіонів кр їни, грол ндш фти якого м ють грунти невисокої родючості. йпоширенішими серед них $є$ дерновопідзолисті, буроземно-підзолисті, поверхнево-оглеєні грунти, що сформув лись н безк рбон тних суглинкових делюві льних т люві льних відкл д х, рідше тр пляються дерново-буроземні т лучно-буроземні грунти [7]. ільшість грунтів досліджув ного регіону з болочен із зн л зн чних змін ун слідок меліор тивних робіт.

сторія розвитку меліор ції н ередк рп тті охоплює три ет пи: перший (1946-1960) - проектув ння т будівництво систем із відкритою мережею к н лів; другий (1961-1975) - будівництво систем із горизонт льним дрен жем; третій - будівництво суч сних систем із двобічним регулюв нням водно-повітряного режиму, т к зв них осушув льно-зволожув льних систем [10].

уч сні грол ндш фти скл д ються з сукупності гроекосистем. кими треб вв ж ти вторинні, тр нсформов ні людиною елемент рні одиниці біосфери, продуктивність яких визн чен господ рською діяльністю й з лежить від економічних і технічних можливостей суспільств [12]. кл довими ч стин ми будь-якої гроекосистеми є рілля, сінож ті, п совищ , б г торічні н с дження, незн чні з площею ре ли лісів, ч г рників, природних лук, боліт, торфовищ, т кож доріг, комунік цій і споруд, що в єдності функціонують як цілісні природно-господ рські комплекси.

грол ндш фтн оцінк осушув них земель повинн охопити суч сний ст н функціонув ння цих земель н всіх компонент х грол ндш фту, що д сть змогу оцінити ступінь їхньої прид тності для з доволення потреб сільськогоспод рського виробництв . н ліз звітних м тері лів обл сних упр влінь земельних ресурсів з свідчив, що площ осушув них земель ередк рп ття ст новить 348,96 тис. г (див. т бл. 1).

структурі осушув них земель 98,7 \% ст новлять сільськогоспод рські землі. еред них пон д $3 / 4$ площі $з$ йнято ріллею, менш ч стк прип д є н п совищ й сінож ті. ерелоги і 6 г торічні н с дження м ють мізерні площі (менше $1 \%$ ).

ільшість земель ередк рп ття $(89,4 \%)$ осушують горизонт льним з критим дрен жем для прискореного відведення з грунту н длишкової вологи. пецифік цього способу поляг є у відведенні поверхневих вод від орного горизонту провідними к н - 
л ми у водоприйм ч х т 3 йвих вод із меліоров ної площі з допомогою регулюв льної мережі. лизько 7,4 \% площі земель осушують відкритою мережею к н лів. ерев жно вони дренують води 3 пл в головних річок т їхніх приток. лише н $3,2 \%$ площі осушув них земель проводять двобічне регулюв ння водного режиму грунту.

дн к пр ктик з свідчує, що перев жн більшість осушув льних систем цього регулюв ння водного режиму м є односторонній х р ктер дії, с ме - відведення н длишкових вод з межі м сивів зрошення.

уч сн структур осушув них земель ередк рп ття

\begin{tabular}{|c|c|c|c|c|c|c|c|c|}
\hline \multirow[t]{2}{*}{ тегорії земель } & \multicolumn{2}{|c|}{ ьвівськ обл. } & \multicolumn{2}{|c|}{$\begin{array}{l}\text { в но- } \\
\text { p нківськ } \\
\text { обл. }\end{array}$} & \multicolumn{2}{|c|}{$\begin{array}{l}\text { ернівецьк } \\
\text { обл. }\end{array}$} & \multicolumn{2}{|c|}{$\begin{array}{c}\text { Г льн площ } \\
\text { осушув них } \\
\text { земель } \\
\text { ередк рп ття }\end{array}$} \\
\hline & тис. $\Gamma$ & $\%$ & тис. $\Gamma$ & $\%$ & тис. Г & $\%$ & тис. $\Gamma$ & $\%$ \\
\hline \begin{tabular}{|} 
ільськогоспод рські \\
землі, \\
у тому числі:
\end{tabular} & 181,81 & 52,17 & 111,3 & 31,85 & 51,17 & 14,64 & 344,28 & 98,66 \\
\hline рілля & 132,25 & 37,9 & 88,15 & 25,3 & 47,08 & 13,5 & 267,48 & 76,7 \\
\hline перелоги & - & - & 2,93 & 0,8 & - & - & 2,93 & 0,8 \\
\hline б г торічні н с дження & 0,113 & 0,03 & 0,25 & 0,07 & 0,19 & 0,05 & 0,55 & 0,15 \\
\hline сінож ті & 23,95 & 6,9 & 5,3 & 1,5 & 1,09 & 0,3 & 30,34 & 8,7 \\
\hline п совищ & 25,35 & 7,3 & 14,39 & 4,1 & 2,48 & 0,7 & 42,22 & 12,1 \\
\hline $\begin{array}{c}\text { сього сільськогоспод рських } \\
\text { угідь: } \\
\text { - із відкритою мережею }\end{array}$ & 181,66 & 52,13 & 111,02 & 31,77 & 50,84 & 14,55 & 343,52 & 98,45 \\
\hline К н лів & 20,64 & 6,27 & - & - & 0,63 & 0,2 & 21,2 & 6,4 \\
\hline $\begin{array}{l}\text { - із з критим дрен жем } \\
\text { - із двобічним регулюв н- }\end{array}$ & 151,18 & 43,1 & 110,06 & 31,5 & 50,55 & 14,5 & 311,79 & 89,1 \\
\hline ням & 9,99 & 2,8 & 1,31 & 0,4 & - & - & 11,3 & 3,2 \\
\hline $\begin{array}{l}\text { нші сільськогоспод рські } \\
\text { землі }\end{array}$ & 0,145 & 0,04 & 0,281 & 0,08 & 0,331 & 0,09 & 0,76 & 0,21 \\
\hline ісові землі & 1,01 & 0,29 & - & - & - & - & 1,01 & 0,29 \\
\hline Г рники & 0,19 & 0,05 & 0,035 & 0,01 & 0,014 & 0,004 & 0,24 & 0,064 \\
\hline будов ні землі & 0,075 & 0,02 & 0,07 & 0,02 & - & - & 0,15 & 0,04 \\
\hline нші землі & 2,58 & 0,7 & 0,34 & 0,1 & 0,36 & 0,1 & 3,28 & 0,9 \\
\hline $\begin{array}{l}\text { сього осушув них зе- } \\
\text { мель різних к тегорій: } \\
\text { - із відкритою мережею } \\
\text { К н лів } \\
\text { - із з критим дрен жем } \\
\text { - із двобічним регулюв н- } \\
\text { Ням }\end{array}$ & $\begin{array}{c}185,67 \\
22,73 \\
152,95 \\
9,99\end{array}$ & $\begin{array}{c}53,23 \\
6,61 \\
43,82 \\
2,8\end{array}$ & $\begin{array}{c}111,75 \\
1,57 \\
108,87 \\
1,31\end{array}$ & $\begin{array}{c}31,98 \\
0,4 \\
31,18 \\
\\
0,4\end{array}$ & $\begin{array}{c}51,54 \\
\\
0,3 \\
51,24\end{array}$ & $\begin{array}{r}14,79 \\
\\
0,39 \\
14,4\end{array}$ & $\begin{array}{c}348,96 \\
\\
24,6 \\
313,06\end{array}$ & $\begin{array}{c}100,0 \\
7,4 \\
89,4 \\
3,2\end{array}$ \\
\hline
\end{tabular}

и про н лізув ли способи осушення земель н десяти н йбільших меліор тивних систем $\mathrm{x}$ ередк рп ття. т бл. 2 н ведено їхні площі, типи осушення т $\mathrm{p}$ йони розт шув ння. 
р ктеристик осушув льних систем ередк рп ття

\begin{tabular}{|c|c|c|c|c|c|}
\hline \multirow[b]{2}{*}{ истем } & \multirow[b]{2}{*}{$\begin{array}{c}\text { лощ , } \\
\text { г }\end{array}$} & \multicolumn{3}{|c|}{ ип системи } & \multirow[b]{2}{*}{\begin{tabular}{ll}
\multicolumn{1}{c}{ йони } \\
розт шув ння
\end{tabular}} \\
\hline & & $\begin{array}{c}\text { із відкритою } \\
\text { мережею } \\
\text { к н лів, г }\end{array}$ & $\begin{array}{l}\text { із з критим } \\
\text { дрен жем, г }\end{array}$ & $\begin{array}{c}\text { із двобічним } \\
\text { регулюв н- } \\
\text { ням, г }\end{array}$ & \\
\hline олозівськ & 11971,0 & 1721,0 & 8484,0 & 1766,0 & $\begin{array}{l}\text { т рос мбірський, } \\
\text { мбірський }\end{array}$ \\
\hline огородч нськ & 10099,0 & 17,9 & 10018,0 & 63,1 & $\begin{array}{l}\text { огородч нський, } \\
\text { исменицький }\end{array}$ \\
\hline орон & 8264,0 & 1487,0 & 6774,0 & 3,0 & $\begin{array}{l}\text { исменицький, } \\
\text { оломийський }\end{array}$ \\
\hline либоцьк & 7400,0 & - & 7400,0 & - & либоцький \\
\hline ерхня іхідр & 6900,0 & 81,0 & 6819,0 & - & ижницький \\
\hline истриця & 5922,0 & 625,0 & 5111,0 & 186,0 & рогобицький \\
\hline торожинецьк & 4800,0 & - & 4800,0 & - & торожинецький \\
\hline лосіретськ & 3600,0 & - & 3600,0 & - & торожинецький \\
\hline иж в & 2621,0 & 869,0 & 1752,0 & - & трийський \\
\hline ковець & 1913,0 & 46,0 & 1867 & - & огородч нський \\
\hline
\end{tabular}

ля визн чення якості функціонув ння н ведених меліор тивних систем розр хов но розподіл осушув них земель у меж х кожної системи (див. т бл. 3).

ні свідч ть, що в структурі земель меліор тивних систем ередк рп ття пон д 60 \% площі прип д є н ріллю. окремих систем х ( либоцьк, торожинецьк , лосіретськ ) н іï̈ ч стку прип д є пон д $90 \%$ площі. сушення перелогів х р ктерне тільки для систем ентр льного ередк рп ття, меліоров ні б г торічні н с дження тр пляються лише н території уковини. інож ті т п совищ 3 йм ють в гомі ч стки в структурі земель усіх систем регіону.

ьогодні в жливою проблемою осушув льних систем ередк рп ття є з безпечення сприятливого меліор тивного ст ну земель. ідсутність технічної експлу т ції, порушення окремих елементів систем ост нніми десятиріччями призвели до їхньої дегр д ції. н слідок цього технічний ст н більшості з них є нез довільним і потребує реконструкції т відновлення. прикл д, з д ними облводгоспу в но- $\mathrm{p}$ нківської обл., зношеність меліор тивних систем ст новить $55 \%$; пр ктично всі водогоспод рські об'єкти потребують ремонту [9]. риблизно т к ж ситу ція скл л ся в ост нні десятиліття й н території ьвівської т ернівецької обл стей.

гідно зі звітними м тері л ми обл сних упр влінь водних ресурсів, екологомеліор тивний ст н осушув них земель ередк рп ття можн оцінити з т кими критеріями:

1) сприятливий - н йбільші площі т ких земель зосереджені в мбірському, т рос мбірському, остиському, ворівському $\mathrm{p}$ йон х ьвівської обл. т в ерц ївському р-ні ернівецької обл. колого-меліор тивний ст н т ких земель д є змогу використовув ти їх пр ктично без обмежень. они є н йприд тнішими для вирощув ння всіх сільськогоспод рських культур т отрим ння високих урож їв;

2) 3 довільний ст н осушув них земель х р ктерний для ородоцького, трийського, икол ївського, ид чівського р йонів ьвівської обл.; олинського, луського, лицького, ожнятівського, огородч нського, исменицького, двірнянського, 
оломийського, осівського, нятинського р йонів в но- $p$ нківської обл.; ижницького, торожинецького, либоцького т іцм нського р йонів ернівецької обл. я к тегорія земель є сприятливою для ведення рослинництв , одн к для отрим ння високих урож їв необхідно постійно з стосовув ти комплекси з ходів щодо їхнього збереження т поліпшення;

3) нез довільний ст н меліоров них земель - н йбільше їх є в рогобицькому т устомитівському р йон х ьвівщини, т кож незн чними площ ми тр пляються в исменицькому і огородч нському $\mathrm{p}$ йон $\mathrm{x}$ в но- $\mathrm{p}$ нківщини. ільськогоспод рське використ ння т ких земель недоцільне, тому першочерговими 3 ход ми є їхня консерв ція т виведення з обігу [2].

озподіл осушув них земель в меж х меліор тивних систем ередк рп ття

\begin{tabular}{|c|c|c|c|c|c|c|c|c|c|c|c|}
\hline \multirow[b]{2}{*}{ тегорії земель } & \multirow[b]{2}{*}{ лощ } & \multicolumn{10}{|c|}{ еліор тивні системи } \\
\hline & & 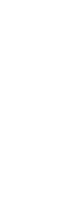 & 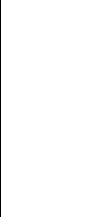 & : & 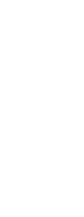 & 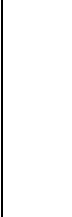 & 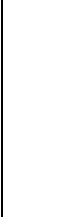 & 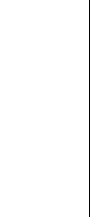 & 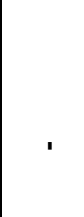 & 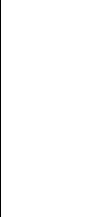 & $\begin{array}{l}\hat{\theta} \\
\stackrel{0}{0} \\
\hat{\theta}\end{array}$ \\
\hline \multirow{2}{*}{$\begin{array}{l}\text { ільськогоспод рські } \\
\text { землі, у тому числі }\end{array}$} & тис. $\Gamma$ & 11,54 & 10,01 & 6,78 & 7,4 & 6,87 & 5,88 & 4,72 & 3,53 & 2,62 & 1,87 \\
\hline & $\%$ & 96,4 & 99,2 & 82,0 & 100,0 & 99,6 & 99,3 & 98,3 & 98,0 & 100,0 & 97,9 \\
\hline \multirow{2}{*}{ рілля } & тис. $\Gamma$ & 8,2 & \begin{tabular}{|l|}
8,81 \\
\end{tabular} & 5,22 & 7,02 & 6,2 & 4,45 & 4,44 & 3,5 & 1,98 & 1,6 \\
\hline & $\%$ & 68,5 & 87,3 & 63,2 & 94,9 & 89,9 & 75,2 & 92,6 & 97,2 & 75,6 & 83,8 \\
\hline \multirow{2}{*}{ перелоги } & тис. $\Gamma$ & - & 0,26 & 0,24 & - & - & - & - & - & - & 0,002 \\
\hline & $\%$ & - & 2,6 & 2,9 & - & - & - & - & - & - & 0,1 \\
\hline \multirow{2}{*}{$\begin{array}{l}\text { б г торічні н с джен- } \\
\text { ня }\end{array}$} & Tис. $\Gamma$ & - & - & - & 0,08 & - & - & - & 0,003 & - & - \\
\hline & $\%$ & - & - & - & 1,0 & - & - & - & 0,08 & - & - \\
\hline \multirow{2}{*}{ сінож ті } & тис. $\Gamma$ & 1,55 & 0,3 & 0,15 & 0,03 & 0,22 & 0,79 & 0,007 & 0,02 & 0,32 & 0,11 \\
\hline & $\%$ & 12,9 & 3,0 & 1,8 & 0,4 & 3,2 & 13,3 & 0,1 & 0,6 & 12,2 & 5,8 \\
\hline \multirow{2}{*}{ п совищ } & тис. $\Gamma$ & 1,79 & 0,64 & 1,16 & 0,14 & 0,45 & 0,64 & 0,27 & 0,004 & 0,32 & 0,16 \\
\hline & $\%$ & 15,0 & 6,3 & 14,0 & 1,9 & 6,5 & 10,8 & 5,6 & 0,1 & 12,2 & 8,2 \\
\hline \multirow{2}{*}{$\begin{array}{l}\text { інші сільськогоспод р- } \\
\text { ські землі }\end{array}$} & тис. Г & - & 0,001 & 0,01 & 0,13 & - & - & - & 0,002 & - & - \\
\hline & $\%$ & - & \begin{tabular}{|l|}
0,01 \\
\end{tabular} & 0,1 & 1,8 & - & - & - & 0,06 & - & - \\
\hline \multirow{2}{*}{$\begin{array}{l}\text { нші землі (крім сіль- } \\
\text { ськогоспод рських) }\end{array}$} & тис. Г & 0,43 & 0,08 & 1,48 & - & 0,03 & 0,04 & 0,08 & 0,07 & - & 0,04 \\
\hline & $\%$ & 3,6 & 0,8 & 18,0 & - & 0,4 & 0,7 & 1,7 & 2,0 & - & 2,1 \\
\hline $\begin{array}{c}\text { г льн площ } \\
\text { осушув них земель }\end{array}$ & тис. Г & 11,97 & 10,09 & 8,26 & 7,4 & 6,9 & 5,92 & 4,8 & 3,6 & 2,62 & 1,91 \\
\hline
\end{tabular}

зв ні к тегорії еколого-меліор тивного ст ну осушув них земель ередк рп ття пок 3 но н рис. 1. 


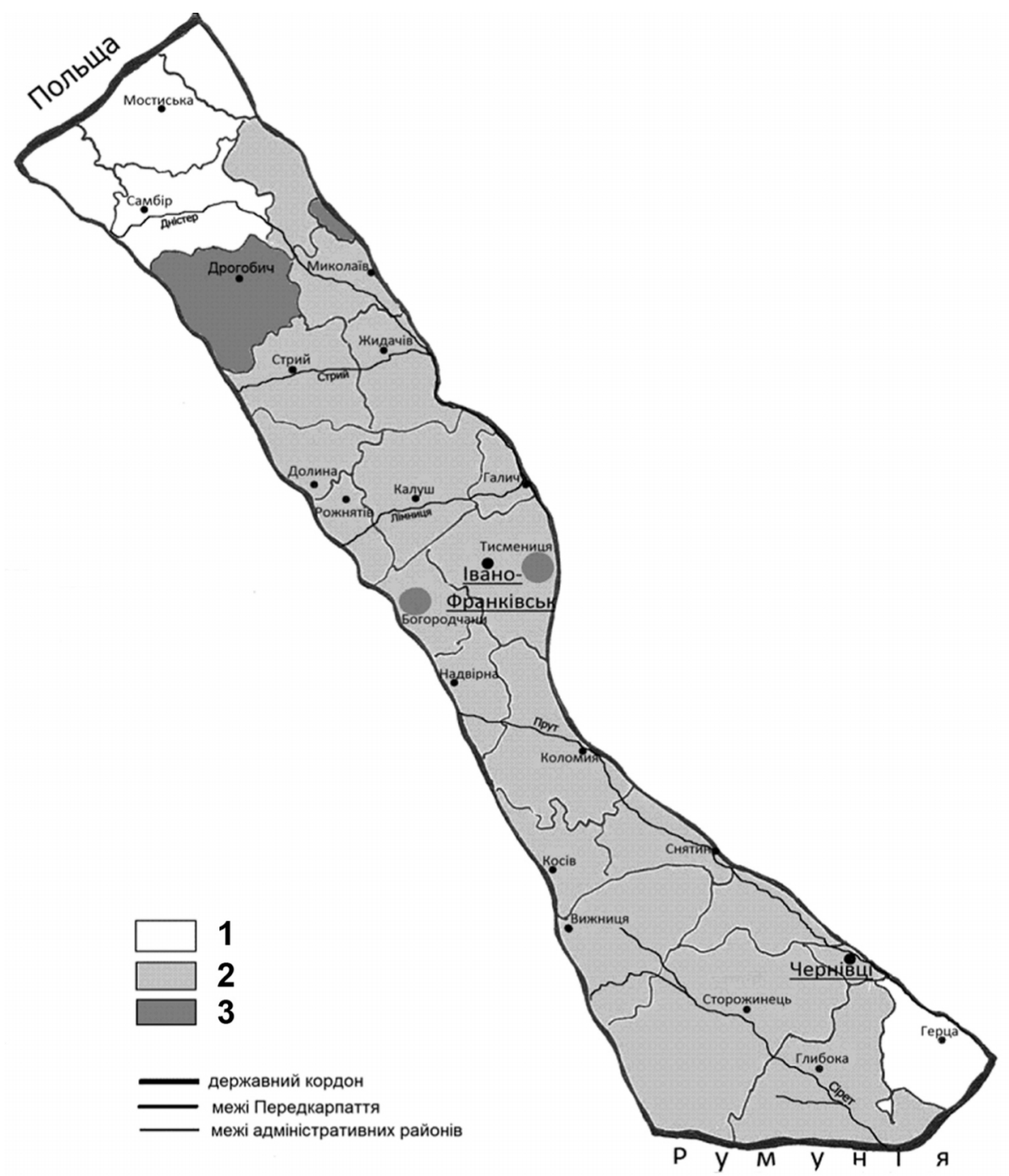

ис. 1. колого-меліор тивний ст н осушув них земель ередк рп ття: 1 - сприятливий, 2 - 3 довільний, 3 - нез довільний.

оловним з вд нням у р зі використ ння осушув них земель будь-якого регіону $є$ отрим ння м ксим льних урож їв т збереження високої родючості грунту. ля н лізу цього пит ння опр цьов но звітні д ні про збір урож ю основних сільськогоспод рських культур із немеліоров них т осушених угідь у 2011 р. н прикл ді ернівецької обл. (див. т бл. 4).

ведені пок зники в т бл. 4 д ють підст ви стверджув ти, що, незв ж ючи н не3 довільний технічний ст н більшості суч сних осушув льних систем, сільськогоспод рським підприємств м вд ється досяг ти високої врож йності. собливо добре це простежується н прикл ді зернових т зернобобових, коли посівн площ цих культур 
н осушених землях у вісім р зів менш, ніж н немеліоров них угіддях, отрим ні врож ї є рівнозн чними, то й дещо перевищують (кукурудз н зерно).

рож йність сільськогоспод рських культур

н немеліоров них т осушених землях ернівецької обл.

\begin{tabular}{|l|c|c|c|c|}
\hline \multirow{2}{*}{$\begin{array}{c}\text { сновні сільськогос- } \\
\text { поські культури и }\end{array}$} & \multicolumn{2}{|c|}{ осівн площ , тис. г } & \multicolumn{2}{|c|}{ рож йність, ц/г } \\
\cline { 2 - 5 } & $\begin{array}{c}\text { нелеров ні } \\
\text { землі }\end{array}$ & $\begin{array}{c}\text { осушені } \\
\text { землі }\end{array}$ & $\begin{array}{c}\text { немеліоров ні } \\
\text { землі }\end{array}$ & $\begin{array}{c}\text { осу шені } \\
\text { землі }\end{array}$ \\
\hline $\begin{array}{l}\text { ернові т зернобобо- } \\
\text { ві, } \text { у тому числі: }\end{array}$ & 132,0 & 11,9 & 45,8 & 44,7 \\
- пшениця озим & & & & \\
- кукурудз н зерно & 38,3 & 5,7 & 38,6 & 36,6 \\
\hline укровий буряк & 64,2 & 3,4 & 58,3 & 74,6 \\
\hline оняшник & 4,7 & 1,5 & 320,7 & 375,5 \\
\hline укурудз н силос & 7,0 & 1,0 & 16,5 & 12,0 \\
\hline ртопля & 3,3 & 0,5 & 188,8 & 177,9 \\
\hline вочі & 33,6 & 0,1 & 186,8 & 149,9 \\
\hline ормові коренеплоди & 12,3 & - & 186,0 & - \\
\hline лодоягідні & 6,8 & - & 264,6 & - \\
\hline
\end{tabular}

еред нег тивних н слідків меліор тивних робіт н ередк рп тті н звемо розвиток ерозії н осушув них землях. йбільше виявляється водн т вітров ерозія н передгірських схил х, що призводить до з мулення земель, особливо меліор тивних к н лів [2], які подекуди з росли ч г рник ми і неспроможні виконув ти покл дені н них функції.

е, відповідно, створює екологічну т технологічну небезпеку для довкілля.

озвитку т ких нег тивних явищ н меліоров них землях посприяло те, що вн слідок зміни системи господ рюв ння більш половин осушув них земель регіону розп йов н між вл сник ми т користув ч ми. е призвело до руйнув ння цілісної структури земель осушув льних систем. емлевл сники не в змозі с мостійно підтримув ти н н лежному рівні ефективне функціонув ння осушув них земель, ун слідок чого вони ст ють безгоспод рними із неп д ють.

тже, меліор тивні з ходи д ли змогу з лучити в сільськогоспод рське використ ння т перетворити в орні землі десятки тисяч гект рів перезволожених земель, які p ніше не використовув ли бо використовув ли м лоефективно, т підвищити родючість грунту. он д $80 \%$ площі осушув них земель ередк рп ття м ють з довільний т несприятливий еколого-меліор тивний ст н. це свідчить, що більшість осушув льних систем регіону потребує комплексної реконструкції т докорінного поліпшення.

\section{СПИСОК ВИКОРИСТАНОЇ ЛІТЕРАТУРИ}

1. люк . . цінк еколого- громеліор тивного ст ну земель нгулецької зрошув льної системи / [ . . люк, . . дних, . . олох , . . едоцюк, . . Ф н сьєв] // існик гр рної н уки. - 2011. - № 7. - . 51-55.

2. щик . . кзогенні процеси н меліоров них грол ндш фт х рик рп ття в суч сних умов х / . . щик // існик ьвів. гр р. ун-ту: землевпорядкув ння і земельний к д стр. - 2010. - № 16. - . 45-52. 
3. щик . . еліор тивний ст н осушув них земель ьвівської обл сті в суч сних умов х / . . щик // існик ьвів. гр р. ун-ту: економік . - 2011. № 18 (2). - .27-31.

4. ожегов . . уково-пр ктичні основи ефективного ведення зрошув ного землеробств / . . ожегов // існик гр рної н уки. - 2012. - № 3. - . 5-8.

5. олощук . . оніторинг пок зників осушених земель ентр льного рик рп ття / [ . . олощук, . . рбівськ , . . ількевич, . . ельник] // існик рик рп т. ун-ту. ер. біол. - 2011. - ип. 15. - . 11-20.

6. еренчук . . риродно-геогр фічний поділ ьвівського т одільського економічних р йонів / . . еренчук, . . ойнов, . . ись. - ьвів : ид-во ьвів. ун-ту, 1964. - 222 с.

7. enym $m$. кологічний ст н грунтового покриву передгірських $\mathrm{p}$ йонів в ноp нківщини / . епут т // існик ьвів. ун-ту. ер. геогр. - 1999. - ип. 25. $.57-58$.

8. змір - рунтоз хисне впорядкув ння грол ндш фтів ьвівщини / . змір // існик ьвів. ун-ту. ер. геогр. - 1999. - ип. 25. - . 128-129.

9. рбівськ. . уч сний ст н осушених земель в но- р нківської обл сті т перспективи їх використ ння / . . рбівськ , . . ельник // існик рик рп т. ун-ту. ер. біол. $-2008 .-$ ип. 10. - . 56-62.

10. озловський. . еліор тивний ст н осушув них земель з хідних обл стей кр їни / . . озловський. - ьвів : вросвіт, 2005. - 420 с.

11. ельник. еліор тивний ст н ет лонних осушув льних систем лого олісся / . ельник // існик ьвів. ун-ту. ер. геогр. - 2007. - ип. 34. - . 153-157.

12. иухно . . ормиров ние грол ндш фтов и охр н природной среды / . . цухно, . . ндер. - инск : нститут геол. н ук , 1995. - 122 с.

m ття: н дійшл до ред кції 03.10.2012

доопр иьов н 05.11 .2012

прийнят до друку 20.02.2013

\title{
DISTRIBUTING OF THE DRIED LANDS IN AGROLANDSCAPE OF FORECARPATHIAN REGION
}

\author{
Natalia Belova \\ Vasyl Stefanyk Precarpathian National University, \\ Shevchenko St., 57, UA - 76018, Ivano-Frankivsk, Ukraine, \\ e-mail: inst@pu.if.ua
}

The modern structure of landscapes of Forecarpathian region in the context of administrative areas was analysed. The major drainage systems of the region are described, the quantitative indexes of lands are resulted on their type of drainage. Investigated the distribution of the dried lands within the irrigation systems and it is given their environmental-meliorative assessment. The examples of highly efficient use of dried lands are showed. Negative ecological processes which develop on the irrigation lands of the region are reflected.

Key words: agricultural landscape, drainage area, drainage system, melioration, Forecarpathian region. 


\section{т лья елов}

рик рп тскийн цион льный университет имени силия теф ник,

ул. евченко, 57, 76018, г. в но- $р$ нковск, кр ин

e-mail: inst@pu.if.ua

ро н лизиров но современную структуру осуш емых земель грол ндш фтов редк рп тья в р зрезе дминистр тивных обл стей. х р ктеризов но н ибольшие осушительные системы регион , приведено количественные пок з тели земель по их типу осушения. сследов но p спределение осуш емых земель в предел х мелиор тивных систем и под но их экологомелиор тивную оценку. риведено примеры высокоэффективного использов ния осуш емых земель. тр жены нег тивные экологические процессы, которые р звив ются н мелиорируемых землях регион .

лючевые слов : грол ндш фт, осуш емые земли, осушительные системы, мелиор ция, редк рп тье. 